\title{
Representational Pattern of Discursive Hegemony
}

\author{
Ming Liu \\ The Department of Foreign Languages, Jiangxi Institute of Education, Nanchang, China \\ Email: jxnulm@126.com
}

Received March 28 $8^{\text {th }}$, 2013; revised May $5^{\text {th }}$, 2013; accepted May $18^{\text {th }}, 2013$

\begin{abstract}
Copyright (c) 2013 Ming Liu. This is an open access article distributed under the Creative Commons Attribution License, which permits unrestricted use, distribution, and reproduction in any medium, provided the original work is properly cited.
\end{abstract}

\begin{abstract}
The paper aims to construct a practical representational pattern, which is to uncover the way the discursive hegemony exists in the content of text. The representational pattern will be embarked upon level by level, mainly from the linguistic perspective such as field of discourse, transitivity, and the choice and meaning of words. For the reason of non-discursive elements having determined effects in the formation of discursive hegemony, the paper will also explore hegemony beyond the linguistic perspective by means of the concept "discourse” constructed in Fairclough's Critical Discourse Analysis model. In addition, a particular written text will be chosen to further testify the way of how hegemony is represented in a particular text or discourse.
\end{abstract}

Keywords: Critical Discourse Analysis; Representation; Hegemony; Manipulation

\section{Introduction}

Hegemony has been extensively expounded from the political, cultural and social aspects (Gramsci, 1971; Augelli, 1988; Baldwin et al., 2004, 2005; Foucault, 1971; Joseph, 2002). In recent years, the concept of hegemony has been explored in Critical Discourse Analysis (Fairclough, 1995, 2003; Dijk, 2001), in which hegemony is generally discussed along with discourse. The relationship between hegemony and discourse has attained enough attentions from analysts of CDA more than other areas' researchers who relate hegemony with non-discursive factors. However analysts of CDA do not elucidate the actual discursive realization of hegemony with linguistic theories.

\section{Discursive Hegemony as Manipulation}

Hegemony in particular social domain is often actualized by means of non-coercive means, such as the dissemination of forms of discourse being a carrier of hegemony. Through analyses of discourse at the level of language, the way of how to represent hegemony in discourse can be shown in terms of field of discourse which is concerned with the whole activities engaged by participants, of transitivity which explores the way of how to construe one particular domain of our experiences, of the lexical level which aims to uncover the significance of choice of words in particular context. At last the concept "discourse" abstractly used by Fairclough will be employed to mediate between the social dimension of hegemony and those linguistic dimensions, and to show the vital role of hegemony in the contemporary society.

\section{Field of Discourse}

A register is a set of meaning potential in a given social context and is more abstract than the immediate situational factors, such as time and space. According to Halliday, a particular text is specified and determined by field, tenor and mode, usually called "three variables of register". In this subsection, we will focus on field of discourse, which deals with social activities in context. Halliday (1978: p. 110) regards field as "the social action in which the text is embedded”. Halliday has characterized field of discourse as follows:

The field of discourse refers to what is happening, to the nature of the social action that is taking place: what it is that the participants are engaged in, in which the language figures as some essential component (Halliday \& Hasan, 1989: p. 12).

According to the level of involvement of language, social action forming a cline has generally been classified into three types without clear boundary (cf. Halliday, 1978: p. 143ff). One type refers to those activities without considering language, which plays little role in concrete activity. In the intermediate type of activity, language functions as a necessary role but still ancillary. Only in another end of the cline, language being one kind of social semiotic plays a vital role in social activity as Halliday once claimed that field includes the subject-matter, as one special manifestation. The reason why Halliday interprets field as subject-matter is that he takes hold on the view of regarding social action as being inherently of a symbolic, verbal nature. Language functions more or less important role in social action which includes daily action and institutional action. Thus field of discourse provides a practicable parameter for researchers who aim to associate language with discursive hegemony by means of the concept "field of discourse". Halliday once used field to analyze a passage from a broadcast talk given by a famous churchman (cf. Halliday \& Hasan, 1989: p. 13ff). He described the field of the passage as "maintenance of institutionalized system of beliefs (religion) and the members' attitudes towards it (semi-technical)”. In the same way, the hegemonic groups (used in the thesis beyond political sense) may disseminate their beliefs, values and 
ideology, and gain support for themselves from other groups. Those beliefs and values communicated in the form of language can be effectively uncovered by using field of discourse.

In this paper, hegemony is not only used in political or economic sense, but also in general sense. For example, the relationship between teachers and students in school may be hegemonic because teachers always dominate students and want to gain support for themselves from students by playing the authoritative role in terms of knowledge. For most time, hegemony occurs at the social institution such as the hegemonic relationship between teachers and students, between doctors and students, between interviewers and interviewees. Faiclough states that

"hegemony is a process at the societal level, whereas most discourse has a more local character, being located in or on the edges of particular institutions - the family, schools, neighborhoods, workplaces, courts of law, etc.” (1995: p. 78).

We agree with the idea of taking hegemony as a process at the societal level, but we assume that hegemony is also located in particular social institution, even in daily conversation just like discourse between parents and children. Discourses of generation, gender, ethnicity, and class channels subjects in very different ways according to the coding orientations they joy (see Martin, 1992: p. 546). So hegemony implied in discourse may depend on those social elements and has different forms in different institutions or arenas. In some institutions, hegemonic relationship between the dominant and the dominated may be forced to take effect by means of coercive ways. In some arenas, especially in less social situation, hegemonic relationship among participants may go into effect in non-coercive ways. The more or less coercive forms can be assessed along the continuum of institutionalization in Figure 1.

In this Figure, we argue that semantic domain can be categorized with respect to institutionalization. In most cases, institutionalization is a matter of degree; the distinction between institutionalized and non-institutionalized semantic domain does not have a clear cut boundary. In addition, the categorization semantic domain can be done with regard to specialization. Thereby the more or less coercive forms can be assessed along the continuum of specialization in Figure 2.

In the contemporary society, social action gets more and more specialized, and hegemony is often organized and institutionalized so that discursive routine can generate effects of discursive hegemony. In other words, field varies along a dimension of specialization as schematized above. The more specialized the field is, the more coercive the hegemonic form takes. For instance, while a professor of SFL is delivering a lecture on register to students who are equipped with little knowledge about linguistics, he uses such technical terms as field, tenor and mode to explain the meaning of register and takes an authoritative role to

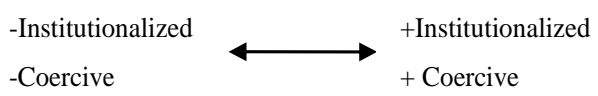

Figure 1.

Hegemonic form and institutionalization of field.

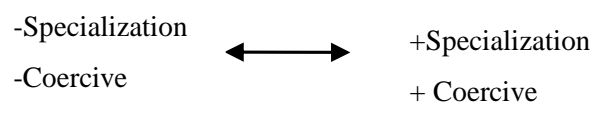

Figure 2.

Hegemonic form and specialization of field. disseminate the specialized knowledge. In terms of this kind of knowledge, the relationship between the professor and his students is unequal; and the professor will take great effect on his students in a coercive way, which means that he takes the form of knowledge to brainwash students' minds in scholastic way and conversely students only act as passive roles and have to accept those "correct" explanation given by their teacher. If supposing a situation in which the professor discusses the performance of Yao Ming (a famous basketball player in NBA) with his students in a casual way, the relationship between the professor of SFL and his students may be more equal than that, just mentioned above. Additionally, it should be emphasized that coercive form may be understood beyond the physical force mainly done by police or state, and may extend to the spiritual one including information or knowledge.

Institutionalization and specialization are two important dimensions of field for discussing hegemonic form taken by the dominant group in a specific semantic domain. In a word, field of discourse provides a practicable parameter for researchers who aim to associate language with discursive hegemony. In the next subsection, we will discuss discursive hegemony along transitivity.

\section{Transitivity}

Transitivity is the representation in language of processes, the participants and the circumstantial elements associated with them. Transitivity refers to the language features of the clause which represent the speaker's or writer's experience or something else around the world, not the narrower meaning as in "transitive and intransitive verbs". The definition of transitivity given by Halliday (1976: p. 21) is that "transitivity is the name for a particular range of meaning potential-the encoding of our experience of processes". According to Halliday, the transitivity system construes the world of experience into a manageable set of process types, the six types of which are material, mental, relational, verbal, behavioral and existential processes. Transitivity is concerned with construing one particular domain of our experience, that is our experience the flux of "goings-on", as configurations of a process (of some general type: material, mental, relational), the participants involved in it (Actor, Goal; Senser, Phenomenon; Carrier, Attribute; and so on), and the circumstances attendant on it (Cause, Location, Manner (including means and instrument), Accompaniment, and so on). The transitivity system of a language will construe experience into a small set of domains of meanings which differ according to the process itself and the nature of the participants involved in it.

The transitivity system provides a resourceful "meaning potential" for language users or interpreters because different process types can be chosen to represent the same content in the world. In the article on Golding's the Inheritors (see Halliday, 1973: p. 103ff), Halliday has shown how selections from the transitivity system can suggest different world-views. Lok, a Neanderthal man, cannot grasp the significance of the actions of "The People" who are invading the territory of Lok's tribe. The main reason for that is Loc uses non-transactive action which is distinct from transactive action performed by "The People". In short, the choosing of process types and the placement of participants and circumstances are largely determined by non-discursive elements as well as hegemonic relationship among interlocutors. As Fowler stated:

Linguistic codes do not reflect reality neutrally; they interpret, organize, and classify the subjects of discourse. They 
embody theories of how the world is arranged: world-views or ideologies (1986: p. 27).

It is natural that discourses of generation, gender, ethnicity and class steer participants in the course of communication in very different ways according to their different coding orientations. Therefore, it is of necessity to introduce the concept "hegemony" into transitivity system for seeing the non-discursive elements underlain in the structure of clause, and vice versa. The unequal relationship between speakers/writers and hearers/readers may have great effect on the choices of process types and the prominence of participants. Consider the following two sentences:

(1) (a) Hornworms sure vary a lot in how well they grow. (b) Hornworms growth displays a significant amount of variations.

It is obvious that the two sentences have different patterning in terms of grammatical devices though they almost represent the same propositional meaning (hornworms change in the course of growing). The main participant of the first sentence is occupied by simple noun hornworms while that of the second sentence by a sort of nominalization hornworm growth which encompasses an abstract meaning which can be expressed by a whole clause hornworms grow. Nominalization as a usual grammatical device used in the scientific discourse often packs a large number of lexical items into one clause, through which the writer can achieve his or her aim of objectification while expressing an idea or concept. Nominalization can be regarded as an effect of the deletion of participants showing impersonality in style. In the second sentence, the expression form of nominalization variations deletes its actor for decreasing the role of the active participant hornworms in the process of variation. What the nomination variations does is to emphasize the objective attitude towards a natural phenomenon. The nominalized language seems like pretentious and may take the meaning obscure and abstract. In addition, the two sentences utilize two different process types to express the same propositional meaning. The first sentence makes use of material process to play emphasis on the dynamics of the Actor hornworms as well as the agency of the participant. Hereby the form of language emotive marker sure is used in the material process with a vague phrase a lot to show the personality in style. However relation process in the second sentence is used to show impersonality in style, and stress the property of the Carrier hornworms growth which means that hornworms growth may undergo the change in size, weight, strength or other aspects.

In some way, the language used in the second sentence is an academic social one whereas the language in the first sentence, according to Gee (2004), belongs to "a vernacular style of language". Both of them reflect two different syntactic patterns, which are dependent on perspectives held by speakers or writers. The vernacular style of language is often concerned with human actors, performing material process in a concrete way, which shows that language user is willing to negotiate outer or inner experiences with other interlocutors. In other words, interlocutors can communicate with each other in a less abstract way, which shows that the relationship between interlocutors in the first sentence is more equal than that in the second sentence if seen from the perspective of manipulation of language.

When the power holder conceals his intent from the power subject - that is the intended effect he wishes to produce, he is attempting to manipulate the latter. In Easton's words:
"When B is not aware of A's intention to influence him but A does in fact manage to get B to follow his wishes, we can say that we have an instance of manipulation” (Wrong, 1979: p. 28).

Manipulation, as one of hegemonic forms, involves reciprocal asymmetrical interaction between interlocutors. The dominant may exercise concealed control over the dominated through symbolic communication, especially language. The manipulation of language in communication or discourse is related to language patterns. Halliday identifies two language patterns: congruent form of language and non-congruent (metaphorical) form of language, which is also called grammatical metaphor, a kind of linguistic phenomenon in which meanings congruently realized by one type of language pattern get realized by other less congruent linguistic units or expressions. The two language patterns can be associated with manipulation, whose relationship is outlined in Figure 3.

The congruent approach to constructing language is less manipulative in terms of the degree of intended influence than the incongruent pattern of language. A typical case in point is that the scientific discourse as the second sentence mentioned above is mainly used to recode original congruent form of language in order to achieve a sort of objective effect and reinforce authority on knowledge. The material process type used in the first sentence has been transformed into the relational process type stressing on the static property of the Carrier hornworms growth. Thus, the second sentence is more manipulative that the first sentence from the perspective of language patterns because it makes the same content more abstract and obscure to understand for laymen. The way of recoding language reflects the social position of language users who dominate and disseminate the socalled scientific knowledge. In some way, the linguistic structure of the second sentence encodes under the transitivity system a scientific world-view and intends to manipulate the vision of readers or hearers in the light of knowledge. Therefore it is reasonable to accept the idea that "the linguistic structure of a text effectively encodes a particular world-view” put forward by Simpson (1993: p. 104).

In general, the transitivity system offers us a useful toolkit to explain the way of how manipulation, as one of hegemonic form, is implied in language.

\section{Discursive Hegemony and Representation}

Hegemony, as a particular way of conceptualizing power, places emphasis on how power depends on consent or manipulation rather than physical force or other explicit coercive forms. In contemporary society, hegemony often embodies a set of institutional norms and other conventional rules in such symbolic forms as newspaper, journal and textbook. In other words, hegemony in the current society takes the discursive form, which becomes an important site of maintaining a variety of power and of struggling over them. Thus, discourse may be the representation of dominant forces to channel the direction of social and cultural changes which is influencing the contemporary society. It is beneficial to explore hegemony at the discursive level as Fairclough argues

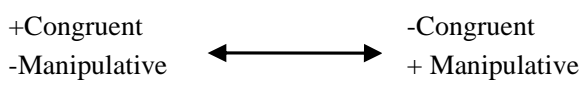

Figure 3.

Manipulation and language pattern. 
that "hegemonic projects are contested in discursive and other modes of practice" (1995: p. 91).

Discursive hegemony is molded out of a series of particular discourses which have more or less legitimate norms on the basis of social hierarchy or other socially naturalized conventions. In addition, hegemony is never the property of an individual; only if the group keeps together does it belong to a group and remains in existence. So, it is natural that hegemony confined to a particular social group must contain a representational point of view in terms of voicing of social events. Different people or social group may encode the same event in distinct way, which is mainly dependent on social conventions formulated by "ideological state apparatuses” (ISAs). ISA, according to Althusser (1971/2001: p. 96), is concerned with "a certain number of realities, which present themselves to the immediate observer in the form of distinct and specialized institutions”. In simple word, an ISA is an institution; modern society contains the religious ISA, the educational ISA, the family ISA, the political ISA, the legal ISA, the trade union ISA, the communication ISA, the cultural ISA, and so on. Those ISAs consisting of a kaleidoscope of gorgeous society represent the same world differently according to their own interests or conventions and then have discourses of their own independent of each other. For instance, the meaning of the word "militant" in trade union ISA is different from than that in political ISA. In the business institution, "militant" is interpreted as a synonym of "activist" whereas it may be used as a synonym of "subversive" in the political institution, both of which take diverse representations by using the same word. However, the lexical item is one of linguistic units that are used to represent the world. There are a number of other linguistic units (especially clause) means to represent our inner and outer experience. Clause, as a way of representing patterns of experience, has been elaborated in detail within the theoretical framework of Systemic Functional Linguistics. According to the linguistic theory, clause, in the sense of experiential function, mainly consists of three components, that is the process, participants in the process and circumstances associated with the process. The grammar of the clause is very useful to explore the particular way of representing the world, not to mention the particular way of conceptualizing power. The choice of the three components in clause reflects the more or less prominence emphasized by interlocutors in order to give voice to their point of views of experiences. Consider, for example:

(2) (a) An Asian male was beaten up in the street.

(b) A man was beaten up in the street.

(c) Someone was beaten up in the street.

The three possibilities considered here represent different ways of linguistically encoding the experience of a particular event. The functional slot (Goal) filled by different nouns shows the degree of suffering the process "was beaten up". In an official occasion, a police officer may prefer using (b) or (c) without mention of the racial identity of the victim. The choice of the participant (Goal) may be influenced by the encoding orientation on the basis of the institutional position held by the police. In the western countries, racism remains one of the most troublesome problems of white society. Public figures, especially those who play major roles in the state society, tend to be careful in the wording. Or else, they will be confronted with criticisms from the public. The Goal someone in sentence (c) is more general than that in sentence (b) and indicates that the police officer is not care about the victim, through which the hidden way of construing power can be uncovered with the help of the specific discursive representation. Of course, in this example, the police officer can, for one reason or another, still privately use (a) to tell the original fact. The choice of the participant an Asian male (Goal) in sentence (a) gives prominence to the racial identity of the victim which shows that s/he takes a fair attitude toward the racial. Thus, the grammar of clause offers us a useful tool to analyze the implicit way of representation of hegemony situating in a series of discourses.

However, hegemonic representation as the police's representation of the racial class is formed out of a particular field in a legal institution or a legal ISA. As mentioned above, social action gets more and more specialized in the contemporary society and hegemony is often organized and institutionalized so that discursive convention has a great effect on discursive hegemony. The more specialized the field is, the more coercive the hegemonic form takes. Political leaders often perform coercively through discourse in setting agendas, choosing topics in conversation and representing the world in a conventional ways. Therefore, in the sense of representation, hegemony implied in language and embedded in social structure can be explained in terms of discursive convention which is in turn molded in particular field of discourse. At the level of language, field of discourse is realized as transitivity which is in turn realized as clause. On the basis of these hierarchical elements, a representation model of hegemony is formulated in Figure 4.

In the process of struggling for discursive hegemony, the dominant as well as the dominated take a great effort to disseminate and control the way of representation for distributing their understanding of the world.

The hegemonic struggle between political forces can be seen as partly a contention over the claims of their particular visions and representations of the world to having a universal status (Butler et al., 2000; cited in Fairclough, 2003: p. 45).

It means that the hegemonic struggle can be exercised through controlling discursive representation. Additionally, discourse as representation can be parsed by means of field, and transitivity at the level of clause. Hereby, it is practical in the sense of theory to analyze discursive hegemony in the representational model.

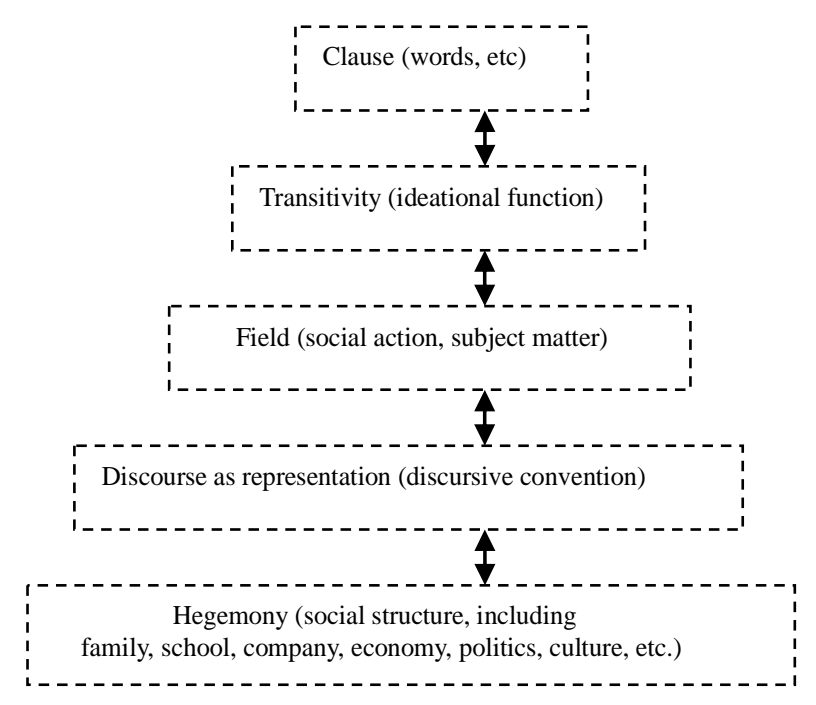

Figure 4.

The representational model of hegemony. 


\section{A Case Study}

Having discussed above discursive hegemony (manipulation) and representation, we shall focus our attention on the linguistic analysis of the political speeches given by President Bush after 11 September event, in order to uncover the manipulative nature implied in those speeches, especially his speech of 11 September $^{1}$ and speech of 20 September Address to a Joint Session of Congress and the American People ${ }^{2}$.

President Bush made one statement on the day when the attacks on the World Trade Centre and the Pentagon took place on 11 September 2001. And he also made the speech of 20 September. The speeches were broadcast across the world and were much debated in the following days and weeks. In some sense, Bush's speeches after 9/11 are important semiotic events in the shaping of discursive meaning and the public's responses. As for the field, Bush's speech construes the world-view that he represents, one of which attempts to construct the group of "enemy". The process of representation can be seen from the cline of nominal groups such as Al Qaeda, the Taliban, the enemies of freedom, and the terrorists. Although the nominal groups fill various functional roles in process types, most of them take the grammatical role of Actor in material process clause (e.g. terrorist attacks can shake the foundations of our biggest buildings; the terrorists who committed these acts (Bush, 2001a); and enemies of freedom committed an act of war against our country; the terrorists practice a fringe form of Islamic extremism...; the leadership of al Qaeda has great influence in Afghanistan and supports the Taliban regime; the Taliban regime is committing murder; these terrorists kill not merely to end lives, but to disrupt and end a way of life; terrorists attacked a symbol of American prosperity (Bush, 2001b)). If using Membership Categorization Analysis (MCA), those nominal groups are classified into "them" as apposed to "us". In other words, the category of "them" is mainly defined by means of action or what they have done to "us". There are several relational clause, which are used to illustrate the identities of "them" (e.g. the terrorists are traitors to their own faith; our enemy is a radical network of terrorists (Bush, 2001b)). As for other processes, there are very few mental and verbal processes in Bush' speeches, which shows that the orator does not care about what the "enemy" thinks and says. Even though mental process has been used several times in the speech of 20 September (e.g. the following clauses Americans are asking, why do they hate us? they hate what we see right here in this chamber-a democratically elected government; they hate our freedoms), these clauses construct a fictitious dialogue to represent the inner experiences of "them". In a sense, the virtual representation of inner world fits an implicit proposition, which refers to that people performing violent actions towards "us" tend to be in hatred of "us". In other words, the relationship between material actions and inner thought conveyed in the mental clauses has been naturalized in language, which is inclined to be accepted by the public or audiences.

The outer actions as well as so-called inner actions have been emphasized and have the function of quickly arousing the pub-

\footnotetext{
${ }^{1}$ Statement by the President Bush in His Address to the Nation in 11 September, 2001 can be accessed at http://www.whitehouse.gov/news/releases/ 2001/09/20010911-16.html.

${ }^{2}$ The speech alone is nearly 3000 words, so it will not be possible to reproduce the text in this thesis. The speech broadcasted and debated across the world can be accessed at

http://www.Whitehouse.gov/news/releases/2001/ 09/20010920-8.html.
}

lic's responses and even hatreds towards “enemies”. In addition, these actions of enemies are ones that can be typically regarded as negative. For Bush, the enemy includes not only those who performed the attacks, but also all those who align themselves with them and support them, which can be seen from Bush's words "from this day forward, any nation that continues to harbor or support terrorism will be regarded by the United States as a hostile regime" (2001b). Those political statements made in political ISA and thus had much more influential than other political texts.

Apart from the process type, the circumstantial elements within the theory of transitivity system deserve to be discussed. The circumstantial factors include time, place, cause, manner, comparison, etc. and play key roles in the whole meaning of process. Bush's speeches concretely represent time whereas space is construed in an abstract way (e.g. today, our fellow citizens... (2001a); we will drive them from place to place (2001b)). The contrast between concrete time and abstract space is prominent in Bush's texts. On the one hand, specific time greatly impresses the public or audiences that the event is real and military actions should be taken immediately. On the other hand, abstract space combines with variety of abstract concepts (e.g. justice, freedom, terrorism) to universalize a certain perspective or interest. "The contention over the claims of their particular vision and representation of the world to having a universal status”, according to Butler et al., 2000, can be called the hegemonic struggle between political forces. In other words, President Bush represents his or the dominant's understandings of social event which are disseminated across the globe. The successful universalization of such a particular representation to a certain extent depends on mediation and articulation.

According to SFL, language is able to construe our experience of the social world. In Bush's texts, language functions the role of manipulating or controlling human behaviors, which has been analyzed at the language level. In a sense, language is actively constituting social processes or rearticulating social events.

\section{Conclusion}

This paper constructs the representational model of hegemony (manipulation), in terms of field of discourse, transitivity system, and discourse (as representation), which is practical to uncover the way of how the discursive hegemony exists in the content of text, and means that discourse may be the representation of dominant forces to channel the direction of understanding of social events. In the sense of representation, hegemony implied in language and embedded in social structure can be explained in terms of discursive convention which is in turn molded in particular field of discourse. The main reason is that individual and institutional actions are to a great extent oriented by institutions and regulations, in which social agents do what they are expected to do or carry out specific discourse.

\section{REFERENCES}

Althusser, L. (1971). Ideology and ideological state apparatuses. In L. Althusser (Ed.), Lenin and philosophy and other essays. New York: Monthly Review Press.

Augelli, E., \& Murphy, C. (1988). American's quest for supremacy and the third world: A gramscian analysis. London: Pinter Publishers.

Baldwin, E., Longhurst, B., Smith, G.., McCracken, S., \& Ogborn, M. (2004). Introducing cultural studies. Beijing: Pearson Education Asia Limited and Peking University Press. 
Bush, G. W. (2001a). Statement by the president in his address to the nation.

http://www.whitehouse.gov/news/releases/2001/09/20010911-16.html

Bush, G. W. (2001b). Address to a joint session of congress and the american people.

http://www.whitehouse.gov/news/releases/2001/09/20010920-8.html

Fairclough, N. (1995). Critical discourse analysis: The critical study of language. London and New York: Longman.

Fairclough, N. (2003). Analysing discourse: Textual analysis for social research. London and New York: Rouledge.

Foucault, M. (1971). The archaeology of knowledge and the discourse on language. New York: Pantheon Books.

Fowler, R. (1986). Linguistic criticism. London: Oxford University Press.

Gee, J. P. (2004). Discourse analysis: What makes it critical? In R. Rogers (Ed.), An introduction to critical discourse analysis in education (pp. 19-50). London: Lawrence Erlbaum Associates Publishers.

Gramsci, A. (1971). Selections from the prison notebooks. London: Lawrence and Wishart.
Halliday, M. A. K. (1973). Explorations in the functions of language. London: Edward Arnold.

Halliday, M. A. K. (1976). System and function in language: Selected papers. London: Oxford University Press.

Halliday, M. A. K. (1978). Language as social semiotic: The social interpretation of language and meaning. London: Edward Arnold.

Halliday, M. A. K., \& Hasan, R. (1989). Language, context and text: Aspects of language in a social-semiotic perspective (2nd ed.). Oxford: Oxford University Press.

Joseph, J. (2002). Hegemony: A realist analysis. London: Routledge.

Martin, J. R. (1992). English text: System and structure. Amsterdam and Philadelphia: Benjamins.

Simpson, P. (1993). Language, ideology and point of view. London and New York: Routledge.

Van Dijk, T. A. (2001). Critical discourse analysis. In D. Tannen, D. Schiffrin, \& H. Hamilton (Eds.), Handbook of discourse analysis (pp. 352-371). Oxford: Blackwell.

Wrong, D. H. (1979). Power: Its forms, bases, and uses. Oxford: Basil Blackwell. 